\title{
Randomized By Mistake Without Study Treatment
}

National Cancer Institute

\section{Source}

National Cancer Institute. Randomized By Mistake Without Study Treatment. NCI Thesaurus. Code C139239.

An indication that the subject was randomized but should not have been, and was subsequently not given study treatment. 